\title{
The Accounting of Consolidation Differences in the European Accounting Practice
}

\author{
Massimiliano Celli ${ }^{1}$ \\ ${ }^{1}$ Department of Management and Law, Roma TRE University, Italy \\ Correspondence: Massimiliano Celli, Department of Management and Law, Roma TRE University, Rome, Via \\ Silvio D’Amico 77, 00145, Italy. E-mail: massimiliano.celli@uniroma3.it
}

Received: September 19, 2019

Accepted: October 15, 2019 Online Published: November 8, 2019

doi:10.5539/ijbm.v14n12p102

URL: https://doi.org/10.5539/ijbm.v14n12p102

\begin{abstract}
This paper aims at recognising the accounting methods for consolidation differences in the IAS/IFRS consolidated financial statements actually utilised by the major parent-companies listed on regulated markets in the lead EU Countries. To this end, first of all the accounting criteria for positive and negative consolidation differences in the consolidated financial statements established by IFRS 3 have been recognised. Then, a sample of No. 250 parent-companies listed on regulated European markets and that prepare their consolidated financial statements in accordance with IAS/IFRS has been selected, in order to ascertain the effective accounting methods commonly used by European business practice. Finally, some aspects of special interest that emerged from the results of the empirical survey will be analysed, together with some questions that the same results have produced.
\end{abstract}

Keywords: consolidated financial statements, financial reporting quality, consolidation differences, IFRS 3

\section{Introduction}

The consolidated financial statement, as is well known, is an accounting document drawn up by a parent company/holding company in order to represent the financial position and the economic result of a business group. In the IAS/IFRS context, it could take on the role of primary financial statement, summarizing and replacing the financial statements of each company belonging to the business group. In the legal systems of some European Countries, on the other hand, the consolidated financial statements do not replace, but rather accompany, the parent company's annual financial statements.

With regard to the preparation of the consolidated financial statements, the need to avoid the phenomenon of the duplication of the group's shareholders' equity is resolved in the phase of the consolidation of equity investments, which consists in the elimination of this item from the financial statements of the parent company and its simultaneous replacement with the algebraic sum of the fair value of the assets and liabilities of the subsidiaries pertaining to the parent company. Normally, this elimination procedure gives rise to more or less wide differences, called consolidation differences and with a positive or negative sign, the accounting treatment of which in our opinion is the stage most exposed to errors in the entire process of preparing the group financial statements.

In the case of negative differences, IFRS 3 (paragraphs 34-36) establishes that they cannot originate from the forecast of future charges, as they are already reflected in the fair values of the assets and liabilities of the acquired entity, but must only be considered as gain from a bargain purchase and therefore charged directly to the consolidated income statement. In the case of positive consolidation differences, IFRS 3 (paragraphs 32-33) assumes that where the acquiring entity is willing to incur a cost higher than the fair value of the shareholders' equity of the acquired company, this higher cost must be lead to a consolidation goodwill. If, on the other hand, it is attributable to an effective overpayment, IFRS 3 does not provide explicitly for its direct allocation to the income statement (although it does not preclude it), but rather for its recognition as goodwill and subsequent reduction in value of the same.

This paper aims at recognizing the accounting methods for the aforementioned consolidation differences (with particular attention to the positive ones) actually followed by the major business groups listed on regulated markets in the main EU Countries, and which prepare their consolidated financial statements in accordance with 
IAS/IFRS Standards. To this purpose, we examine No. 250 consolidated financial statements drawn up by as many European parent companies that have made at least one acquisition of controlling interests in the period 2012-2017, in order to ascertain:

- the statistical frequency of the above mentioned No. 3 methods of accounting for consolidation differences, and if there is a statistical homogeneity between the different Countries;

- whether the quantitative and qualitative data provided in the notes to the said consolidated financial statements are adequate to provide a clear and correct representation of the said consolidation operations, in accordance with the general accounting standards established by both IAS 1 and the Conceptual Framework for Financial Reporting.

The article is organised as follows. The following section provides a literature review of the topic. In section 3 the objectives of the current research are explained analytically. In section 4 the methods for calculating, and subsequently accounting for, positive and negative consolidation differences in the consolidated financial statements are illustrated in the light of the provisions of IFRS 3 and the related interpretative principle. In section 5 the methods for accounting for the consolidation differences in the consolidated financial statements actually used by the major industrial groups listed on the main European regulated markets will be identified. In paragraph 6 , we draw some conclusions on the topic at stake.

\section{Literature Overview}

As mentioned above, the issue of determining and subsequently allocating to the consolidated financial statements, the differences emerging from the consolidation of controlling interests is the most "tricky" moment in the entire process of preparing the consolidated financial statements, and it has been the object of numerous studies that aimed to detect the causes as well as identifying the most appropriate methods for measuring and then recording them in the Group accounting.

In the last century a branch of studies was developed to try determining the most suitable methods for calculating positive and negative consolidation differences (Basioudis, 2019; Cairns, 2009). Specifically, there are two schools of thought (Moonitz, 1998; Marchi, 2011) that have led to two consolidation theories (Parent Company Theory and Entity Theory, from which variants more or less accepted by international accounting practice, such as the Modified Parent Company Theory, have been derived), which we will see in the next chapter have both been implemented, alternatively, by the IFRS 3 (Cotter, 2012; Christensen, Cottrell \& Baker, 2013).

No less important is the strand of studies, closely linked to the previous one, concerning the identification of the most correct methods of accounting for consolidation differences (Pesci \& Andrei, 2011; Gornik-Tomaszewski $\&$ Larson, 2014). In particular, one of these orientations is inclined towards the analytical determination of the individual causes of the consolidation differences (Dyck \& Zingales, 2004; Beaver, Correia \& McNichols, 2011; Padmini \& Narasimhan, 2012) then giving each adequate evidence in the consolidated financial statements. Another approach, on the other hand, is to record such differences as they are (i.e. without their prior attribution, obviously within the limits of the relative fair values, to the equity items of the subsidiary that determined them) directly in the consolidated financial statements under indistinct items (Verriest \& Gaeremynck, 2009; Muller, 2011; Kapadia, 2011).

Considerable attention has also been paid by international scholars and researchers to the representation in the consolidated financial statements of the interests of corporate minorities (obviously in the event that the controlling interest is not $100 \%$ ), and in particular to the determination and subsequent accounting of the portion of consolidation goodwill attributable to these minorities (Muller, 2014; Azzali, 2006; Sedki, Smith \& Strickland, 2014).

\section{Recognition in the Group's Financial Statements of Consolidation Differences in Accordance with IFRS 3}

IFRS No. 3 establishes the criteria for measuring, presenting in the consolidated financial statements and disclosing information about business combinations involving the transfer of control (Note 1).

According to this principle, business combinations consist of the complex of transactions that combine several companies or activities into a single economic entity. This assumption results in the acquisition by a well-identified entity of the control over one or more distinct economic activities.

The notion of control shall mean as the power to determine the financial and operating policies of an entity in order to obtain economic benefits. The concept of financial policies refers to the choices related to the financial management of a company, encompassing, for example, the distribution of dividends, the approval of budgets, 
accounting policies, etc. The notion of management policies, on the other hand, covers all those activities that govern the operations of an economic entity, such as the management of sales, commercial and marketing policies, human resources, etc. (Note 2).

Over the years, since its first introduction in 2003 to replace the former IAS 27, IFRS 3 has been the subject of numerous and, in some cases, significant additions/amendments by the IASB, in order to make it as close as possible to the social phenomena that it is responsible for regulating in the technical-accounting sense. In its latest version (2018) this standard provides, as the only method of accounting for business combinations, the Acquisition Method which replaced the Purchase Method in 2008 (Basis for Conclusions of IFRS 3 - BC 24-28), which consists of the following application phases (in chronological order of succession):

1) Preliminary assessment of the requirements for the application of IFRS 3 to the business transaction in question (in particular, whether or not it can be considered a business combination);

2) Determination of the date of acquisition of control by the acquirer of the entity (usually the date of transfer of consideration and acquisition of the net assets of the acquirer), by reference to which the value of any consolidation difference shall be calculated (BC 106-110);

3) Identification of the acquirer, i.e. the entity that obtains control of the businesses involved in the combination;

4) Determination of the acquisition cost (BC 111-311), given by the sum of the fair values of the assets sold, the liabilities assumed and the equity instruments issued, as well as any other cost directly attributable to the business combination (substantially, the acquisition cost is given by the amount of money transferred to the seller). If the acquisition took place through an exchange of shares, the fair value of the acquired entity, and therefore the cost of the acquisition, is given by the stock exchange price of the shares issued by the purchaser at the exchange date (Note 3);

5) Allocation of the cost of the combination, at the acquisition date, on the assets and liabilities of the acquired entity, representing $100 \%$ of its fair value:

- The identifiable assets of the acquirer, only if it is probable that they will generate economic benefits in the future and if their fair value can be measured reliably;

- Identifiable liabilities other than potential liabilities, for which a future financial outlay is therefore probable;

- Contingent liabilities and intangible assets falling within the definition of intangible assets pursuant to IAS 38 (Note 4), only if their fair value is reliably and prudently measurable (Note 5) because they are not present in the financial statements of the acquired entity;

6) Calculation and subsequent recognition in the financial statements of goodwill or losses arising from the combination (BC 312-382) and resulting from the difference between the acquisition cost and the fair value of the equity acquired (this is therefore the part of the acquisition cost that cannot be allocated to the assets and liabilities of the entity acquired).

A positive consolidation difference can be considered:

- A goodwill (to be calculated, at the discretion of the parent company's accounting management, according to the Partial Goodwill Method, inspired by Parent Company Theory and which represents in the consolidated financial statements only the goodwill pertaining to the purchaser - Note 6, or according to the Full Goodwill Approach, referring to the Entity Theory and which also shows in the financial statements the goodwill pertaining to non-controlling interests - Note 7), which in the light of the provisions of IAS 38 (paragraphs 107-110) must be recorded among the assets of the balance sheet and therefore subject to periodic impairment testing in accordance with IAS 36. The surplus in question may include several components: $i)$ the goodwill of the acquired entity (fair value of the going concern element of the acquirer), recognized on the basis of the prospective earnings capacity of the company in which the investment is acquired, taking into account, among other things, the tangible and intangible assets, the competitive position, the market share and the barriers to entry of the acquired entity at the time of exchange; ii) the goodwill deriving from the synergies expected from the business combination.

- An overpayment when it cannot be considered as goodwill in the light of the requirements of IAS 38. In this case IFRS 3 and the Basis for Conclusions of IFRS 3 do not provide explicitly for its direct allocation to the consolidated income statement (although it does not preclude it) but rather for its recognition as goodwill and subsequent (in any case in the same year as the first registration) reduction in value of the same. 
A negative difference, instead, which occur when the net fair value of the identifiable assets, liabilities and contingent liabilities of the acquired entity exceeds the cost of the business combination, IFRS 3 establishes that it cannot be considered as a badwill because they cannot originate from the forecast of future charges as they are already reflected in the fair values of the assets and liabilities of the acquired entity, and so they must only be considered a real gain from a bargain purchase and therefore charged directly to the consolidated income statements.

\section{Study Objectives}

In our study, we try to ask the following questions:

1) Is there statistical uniformity in the way consolidation differences are accounted for by the No. 250 European parent companies of the research sample?

2) Are the reasons for the recognition of goodwill from consolidation, as well as the related calculation methods, adequately explained (both in qualitative and quantitative terms) in the notes to the consolidated financial statements?

3) Are there any quantitatively significant write-downs of the consolidation goodwill following an impairment test in the year of first recognition or in the next year? If so, are they adequately explained (both in qualitative and quantitative terms) in the notes to the consolidated financial statements?

\section{Study Design and Results}

\subsection{Research Methodology and Data Design}

Through the use of the Amadeus and Aida databases this research focused on industrial parent companies (therefore excluding banks, insurance companies and financial companies) listed on regulated markets of the following EU Countries: France, Germany, Spain, Italy and the United Kingdom.

For each of the Countries considered, the sample is made up of the first No. 50 parent companies in order of annual turnover, which have made at least one acquisition of controlling interests in the period 2012-2017 (for a total number of consolidated financial statements analized equal to No. 250).

As mentioned above, the cases that may occur are as follows:

1) The amount of the transaction is equal to the fair value of the net assets, and therefore there are no consolidation differences (a very rare assumption in reality);

2) The amount of the transaction is greater than the fair value of the net assets, with the consequent emergence of a positive consolidation difference whose determinants may alternatively be goodwill (to be recorded in the consolidated balance sheet) or overpayment (to be recorded in the consolidated income statement);

3) The amount of the transaction is lower than the fair value of the net assets, with the consequent emergence of a negative consolidation difference which for IFRS 3 must always be considered a gain from a bargain purchase (and so recorded in the consolidated income statement).

Therefore, for each of the Countries considered, it has been ascertained how many of the 50 parent companies included in the sample accounted a negative consolidation difference in their consolidated financial statements and how many a positive consolidation difference.

Consequently, with regard to the parent companies that accounted a positive consolidation difference, it was verified how many of them had recorded it in the consolidated balance sheet as goodwill and how many, instead, had recorded it in the consolidated income statement as overpayment.

With regard to the parent companies which accounted the positive difference as goodwill, it was verified, through the analysis of the Notes to the consolidated financial statements, whether or not in the same year in which the goodwill was first accounted in the consolidated financial statements, or in the year following, the parent companies made a write-down of the original value of goodwill following an impairment test, and if so, to what extent.

\subsection{Data Results and Analysis}

With reference to the sample of Italian parent companies (No. 50), only 2 recognised a negative consolidation difference, while the remaining 48 recognised a positive consolidation difference. Of these 48 , as many as 45 parent companies recorded the positive difference as goodwill in the consolidated balance sheet, while only 3 parent companies recorded it as overpayment in the consolidated income statement. 
With reference to the sample of Spanish parent companies (No. 50), only 3 recognised a negative consolidation difference, while the remaining 47 recognised a positive consolidation difference. Of these 47 , as many as 46 parent companies recorded the positive difference as goodwill in the consolidated balance sheet, while only 1 parent companies recorded it as overpayment in the consolidated income statement.

With reference to the sample of French parent companies (No. 50), all of them recognised a positive consolidation difference. Of these, as many as 48 parent companies recognized the positive difference as goodwill in the consolidated balance sheet, while only 2 parent companies recorded it as overpayment in the consolidated income statement.

With reference to the sample of German parent companies (No. 50), only 1 recognised a negative consolidation difference, while the remaining 49 parent companies recognised a positive consolidation difference. The latter has been always recorded in the consolidated financial statements as goodwill (therefore no overpayment hypotheses were found).

With reference to the sample of English parent companies (No. 50), all of them recognised a positive consolidation difference that was always recorded as goodwill in the consolidated balance sheet.

Sintetically:

\begin{tabular}{lccc}
\hline & Negative differences & \multicolumn{2}{c}{ Positive differences } \\
& & 2 & 48 \\
France & - & 3 & 45 \\
Italy & 2 & - & 49 \\
Germany & 1 & - & 50 \\
Great Britain & - & 1 & 46 \\
Spain & 3 & $\mathbf{6}$ & $\mathbf{2 3 8}$ \\
& $\mathbf{6}$ & &
\end{tabular}

In light of the above, it should be noted that out of a sample of 250 European parent companies that in the period 2012-2017 made at least one acquisition of controlling interests, as many as 244 recognised a positive consolidation difference $(97,6 \%)$, of which as many as 238 recorded it as goodwill $(97,5 \%)$ and only 6 an overpayment $(2,45 \%)$.

From the analysis of the notes to the consolidated financial statements, it was pointed out that of the aforementioned 238 parent companies, No. 164 (69\%) calculated goodwill using the Partial Goodwill Method (consequently not showing the goodwill attributable to non-controlling interests in the consolidated financial statements) while the remaining used the Full Goodwill Method. Moreover, the notes under examination in no case provided precise and complete information, from both a quantitative and qualitative point of view, with regard to the aforementioned accounting entry.

As is well known, according to the provisions of IAS 36, goodwill recorded in the financial statements (regardless of the methodology used to calculate it: Full Goodwill Method or Partial Goodwill Method) must be subject to periodic impairment test. An analysis of the notes to the abovementioned No. 238 consolidated financial statements has therefore been used to determine whether and, if so, to what extent the goodwill recorded therein has been written down in the same year or in the year following that in which it was first recorded.

Of the 238 parent companies mentioned above that recorded the positive consolidation difference in the consolidated financial statements as goodwill, none recorded a loss in value of the goodwill in the year of first recognition, but No.102 (43\%) recorded a loss in value of the goodwill in the year following that in which it was initially recorded. In a significant number of cases (No. $32-31 \%$ ), the write-down of the goodwill was such as to reduce its value to zero.

Again, the information contained in the notes to the consolidated financial statements of these parent companies is not sufficiently precise and exhaustive to clarify the calculation methods and the assumptions (events, environmental contexts, etc.) that led to the aforementioned write-downs.

\section{Discussions and Conclusions}

With regard to the objectives of this research specified in section 3 , it should be noted that:

1) There is statistical uniformity in the way consolidation differences are accounted for by the No. 250 European parent companies of the research sample. The frequency with which goodwill from consolidation, 
overpayment and gain from a bargain purchase are accounted in the examined consolidated financial statements is practically identical in the 5 European Countries examined in the survey.

2) The reasons for the recognition of goodwill from consolidation, as well as the related calculation methods, are not adequately explained (both in qualitative and quantitative terms) in the notes to the consolidated financial statements. All 238 companies only indicate the Full Goodwill Method or Partial Goodwill Method used.

3) In the year of first recognition of goodwill, none of the 238 companies mentioned above made write downs of the consolidation goodwill following an impairment test. No. 110 (46\%) parent companies recorded a loss in value of the goodwill in the year following that in which it was initially recognized. In a significant number of cases (No. 43 - 39\%), the write-down of the goodwill was such as to reduce its value to zero.

4) None of the aforementioned 102 parent companies that wrote down goodwill from consolidation in the year following the year of initial recognition adequately justified this operation (in qualitative and quantitative terms) in the notes to the consolidated financial statements.

In our opinion, the results of the empirical survey highlight some interesting aspects regarding the accounting of positive consolidation differences, and that's the high statistical frequency of goodwill recording as well as its accounting treatment in the years following that of the first recognition in the consolidated financial statements.

Specifically:

a) In absolute terms, in $95,2 \%$ of the consolidated financial statements examined the consolidation operation gave rise to the recognition of goodwill from consolidation, while only $2,4 \%$ of the cases were accounted for as overpayment directly. In our opinion, this very high statistical frequency is hardly correlated to the historical period considered (2012-2017) which, as is well known, was negatively influenced (at least in the first three years) by the combined effects of the international financial crisis (which broke out in the US in 2008 but whose effects spread late in Europe and lasted for a long time) and the European sovereign debt crisis that broke out in 2012, which had considerable repercussions on the economic and productive systems of all EU member Countries (in terms of the fall in the market prices of practically all the corporations, decrease in turnover, increase in bankruptcy rates, etc.);

b) With reference only to the parent companies that have recorded goodwill from consolidation, moreover, in $43 \%$ of cases they have then written it down in the year following that in which it was initially recorded (in $31 \%$ of cases this write-down has completely zeroed the entire value of the goodwill itself). In this regard, we wonder whether it would not have been preferable, for the purposes of a more truthful and correct representation of the equity, financial and economic situation of the group as a whole, to carry out already in the year of first recording an adequate write-down of such goodwill (as, moreover, provided for by IFRS 3) or even better to record the positive difference of consolidation, in whole or in part, directly in the consolidated income statement as overpayment. In fact, maybe the causes of such significant write-downs of goodwill from consolidation in the year following the year of first recognition (and which often led to its complete zeroing) were reasonably foreseeable, at least partially, in the year of first recognition.

The qualitative and quantitative data contained in the notes to all the consolidated financial statements examined for the purposes of this research did not allow the above-mentioned aspects to be examined in greater depth. Given that at present there is no obligation under any accounting standard to provide such information in the notes to the consolidated financial statements, it may be appropriate for the International Accounting Standard Board, as part of a future review of both IFRS 3 and IFRS 10, to include certain (obviously simplified) provisions in this respect.

\section{References}

Azzali, S. (2006). Reddito e patrimonio dei soci di minoranza. In: Andrei P., L'adozione degli IAS/IFRS in Italia: concentrazioni aziendali e bilancio consolidato. Torino: Giappichelli.

Basioudis I. (2019). Financial Accounting. Routledge.

Beaver, W. H., Correia, M. M., \& McNichols, M. (2011). Financial statement analysis. Boston: Now Publishers Inc.

Cairns D. (2009). Applying International Accounting Standards. London: Butterworths.

Christensen, T., Cottrell, D., \& Baker, R. (2013). Advanced Financial Accounting. McGraw-Hill, NY.

Cotter, D. (2012). Advanced Financial Reporting - A Complete Guide to IFRS. Harlow: Prentice Hall. 
Dyck, A., \& Zingales, L. (2004). Private Benefits of Control: An International Comparison. The Journal of Finance, 59(2), 537-600. https://doi.org/10.1111/j.1540-6261.2004.00642.x

Gornik-Tomaszewski, S., \& Larson, R.K. (2014). New Consolidation Requirements under IFRS. Review of Business, 35(1), 47-58. https://doi.org/10.1016/j.intaccaudtax.2006.08.003

Kapadia, N. (2011). Tracking down distress risk. Journal of Financial Economics, 102(1), 167-182. http://dx.doi.org/10.1016/j.jfineco.2011.05.0044

International Accounting Standards No. 1 (IAS 1) - Presentation of Financial Statements

International Financial Reporting Standards No. 3 (IFRS 3) - Business Combinations

International Financial Reporting Standards No. 10 (IFRS 10) - Consolidated Financial Statements

Marchi L. (2011). I metodi di consolidamento nei bilanci di gruppo. Giappichelli, Torino, pp. 1-310.

Moonitz, M. (1998). Consolidated Statements. In Accountants Handbook. Roland, London, pp. 1-443.

Muller, V. O. (2014). The impact of IFRS adoption on the quality of consolidated financial reporting. Social and Behavioral Sciences, 109(2014), 966-992. https://doi.org/10.1016/j.sbspro.2013.12.574

Muller, V. O. (2011). Value relevance of consolidated versus parent company financial statements: evidence from the largest three European capital market. Journal of Accounting and Management Information Systems, 10(3), 326-350. http://dx.doi.org/10.1111/j.1468-5957.1990.tb00555.x

Padmini, S., \& Narasimhan, M. S. (2012). The value relevance of consolidated financial statements in an emerging market. Asian Review of Accounting, 20(1), 58-93. https://doi.org/10.1108/13217341211224727

Pesci, C., \& Andrei, P. (2011). An Empirical Investigation into the Boundary of Corporate Social Reports and Consolidated Financial Statements. Social and Environmental Accountability Journal, 31(1), 73-84. https://doi.org/10.1080/0969160X.2011.556404

Prencipe, A., Tettamanzi, P., \& Mancini, C. (2017). Bilancio Consolidato, Egea, Milano, pp. 1-360.

Sedki, S. S., Smith, A., \& Strickland, A. (2014). Differences and Similarities Between IFRS and GAAP on Inventory, Revenue Recognition and Consolidated Financial Statements. Journal of Accounting and Finance, 14(2), 120-143. http://dx.doi.org/10.1016/0378-4266(81)90029-7

Verriest, A., \& Gaeremynck, A. (2009). What determines goodwill impairment? Review of Business and Economics Literature, 54(2), 106-128.

\section{Notes}

Note 1. Therefore, combinations of entities subject to common control are excluded from the application of IFRS 3 , as there is no change in the entity's control as a result of the transaction.

Note 2. An in-depth analysis of the multiple concepts of control under IFRS 3 requires specific research and therefore falls outside the scope of this study.

Note 3. From a purely accounting point of view, extraordinary operations, whether mergers, demergers, contributions of companies or business units, acquisitions of companies, business units or shareholdings, are all considered "acquisitions", i.e. operations with which the exchange of company assets is carried out for consideration, whether it is represented by money, shares, credits or other activities. In any case, the analysis of these aspects is particularly complex and therefore we refer you to specific studies on their deepening.

Note 4. Under IAS 38 an intangible asset is considered identifiable if it can be separated or separated from the entity to which it relates and then sold, transferred, licensed, rented or exchanged individually.

Note 5. The preferred method for estimating the value of an intangible asset is to refer to quotation prices on an active market considering the current offer price. If current prices are not available, or if there is no active market, it is necessary to use alternative criteria to determine them, for example by drawing on the valuation techniques most widely used in international business practice. In any case, the analysis of these aspects is particularly complex and therefore specific studies should be consulted for further information.

Note 6. In this regard, therefore, goodwill arising on consolidation represents, for the acquirer alone, a payment made in anticipation of future economic benefits arising from assets of the acquired entity that cannot be individually identified and separately recognized in the consolidated financial statements. 
Note 7. Please refer to further studies for an analysis of how goodwill and minority interests are calculated on the basis of these theories.

\section{Copyrights}

Copyright for this article is retained by the author(s), with first publication rights granted to the journal.

This is an open-access article distributed under the terms and conditions of the Creative Commons Attribution license (http://creativecommons.org/licenses/by/4.0/). 